\title{
ILCEA
}

Revue de l'Institut des langues et cultures

d'Europe, Amérique, Afrique, Asie et Australie

$31 \mid 2018$

Récits fictionnels et non fictionnels liés à des

communautés professionnelles et à des groupes spécialisés

\section{Narrative, Identity and Academic Storytelling}

Narrations, identités et récits académiques

\section{Ken Hyland}

\section{(2) OpenEdition}

\section{Journals}

Electronic version

URL: http://journals.openedition.org/ilcea/4677

DOI: 10.4000/ilcea.4677

ISSN: 2101-0609

Publisher

UGA Éditions/Université Grenoble Alpes

Printed version

ISBN: 978-2-37747-043-3

ISSN: 1639-6073

\section{Electronic reference}

Ken Hyland, " Narrative, Identity and Academic Storytelling », ILCEA [Online], 31 | 2018, Online since 06 March 2018, connection on 30 April 2019. URL : http://journals.openedition.org/ilcea/4677 ; DOI 10.4000/ilcea.4677

This text was automatically generated on 30 April 2019.

(c) ILCEA 


\section{Narrative, Identity and Academic Storytelling}

Narrations, identités et récits académiques

Ken Hyland

\section{Introduction}

1 Most simply, a narrative is a spoken or written account of connected events: a story. Narratives in the social sciences, particularly those elicited through biographical interviews, have become the preferred method of data collection for researchers interested in identity and the connections between structure and agency (e.g. Block, 2006). The idea is that identity can be explored through the stories we tell about ourselves, tapping into the accounts that individuals select, structure and relate at appropriate moments. The underlying emphasis is on reflexivity and the belief that storytelling is an active process of summation, where we re-present a particular aspect of our lives. Giddens (1991) argues that self and reflexivity are interwoven so that identity is not the possession of particular character traits, but the ability to construct a reflexive narrative of the self. Identity comprises many narratives that a person constructs for him or herself which can vary with time and occasion.

In other words, narrative theorists argue that by analysing the stories people tell about themselves we can understand how they make their lives coherent and meaningful. Identity thus becomes salient and available for analysis, showing how people experience their lives as members of particular social groups. Despite their popularity, however, I would argue that interviews are a poor means of understanding identity. The narratives they produce are a self-conscious assembling of experience for a complete stranger from the local university. They have little real-world significance or consequences for the subject and are produced in a relatively formal and contrived context. Most of the time we are not performing identity work by narrating stories of ourselves into a researcher's microphone but claiming identities while engaged in doing something else. If identity is 
really a performance and not an interpretive recounting then we need to explore narrative in the genres people routinely use in their everyday lives.

3 This position would, of course, be contested by those such as Gilbert and Mulkay (1984) who see interviews as a way of getting at "contingent" and therefore more authentic aspects of science. For them, published papers presented the "empirical" or tidied up versions of research designed for a public audience. While I agree that we might understand, talk about and practice science in less formal and provisional ways, it is the public account which gets attention, accumulates credit and builds reputations. The public voice is the one which is heard and when we explore identity it is how others see us, rather than what we do privately, that contributes to our persona. It is in our public representations that identities are recognised, modified and challenged-identity is not merely a self-representation but a public one, even if this is carefully manipulated to project the professional image we desire. We need, in other words, to look at the nonfictional narratives that members of particular professional communities engage in to tell their stories. As Roland Barthes observes, "There is a prodigious variety of genres [...] which can be used to accommodate man's stories” (1975: 237) and in this paper I am going to focus on three which are commonplace in academic life. In fact they are so ubiquitous as to be almost invisible: acknowledgements, homepages and bios.

\section{Narrative genres, academic communities and corpus data}

4 I am partly attracted to these genres by their ordinariness. The fact that they are part of the taken-for-granted background of academic life requires their writers to conduct no research to produce or careful analysis to craft. Neither strictly academic nor entirely personal, they do not carry the weight of academic texts which are critiqued by colleagues and assessed by review boards. They stand outside the research record but have a considerable socio-pragmatic relevance which makes them integral to it. My main reason for this selection, however, is that these genres are sites of professional exposure: they are places where academics can talk about themselves most explicitly. Acknowledgements, homepages and bios are therefore somewhat unusual in providing personal spaces for self-representation and story-telling, and exist in contrast to the anonymized, pseudo-objective, author-evacuated prose of mainstream academic work.

Often students and academics feel uncomfortably positioned, even alienated, by the impersonal conventions of academic discourse. They complain that the voice they are required to adopt in their dissertations, articles and monographs require them to "talk like a book" and this forces them to adopt an overly formal and coldly analytical persona which doesn't represent who they feel they "are". Ivanic (1998), for example, argues that a writer's "discoursal self" is socially constructed by the "socially available possibilities for selfhood" made available in the text and that her mature students had a sense of disowning part of the self they were required to use in the privileged discourses of the academy. In contrast, bios, acknowledgements and webpages provide venues for narrative self-representation which offer opportunities for writers to craft a more personal or "authentic" identity. So, in different ways, they are story-telling genres, and in them we can read the stories academics tell about themselves and the identities they are trying to create by doing so. 
6 Identity is a significant aspect of the relationship between individuals and institutions, and as a result is inscribed in the discourse choices made by community members when participating in valued genres. Whenever we speak we do so from within a specific "regime of language" (Kroskrity, 2000) and this is often not a matter of conscious individual awareness, but of routine and habit, accumulated, acquired and changed through myriad repeated interactions. This is what Bourdieu referred to as "habitus" and Foucault as our "archive": the partially visible discursive systems which we take for granted and operate within. In other words, disciplinary discourses are evidence of mutual recognition and preferred patterns of alignment and we can recover something of these alignments and preferences through the study of collections of texts. Corpora are important here as they represent a speaker's experience of language in a restricted domain and so provide evidence of typical choices in that domain.

7 Corpora haven't really been exploited as a way of looking at identity but they provide evidence of how we typically use language in a given context. So, by "dematerializing texts" away from actual concrete instances a corpus approach provides linguistic evidence of consistent rhetorical choices. Mapping typicality, it shows what is usual and what is deviant in collections of texts and so helps to reveal both underlying discourses and individual preferences. It brings to identity research evidence of how individuals, repeatedly and routinely, position themselves in relation to their readers so that in constructing knowledge and relationships they also construct themselves. In corpora, then, are traces of routine community practices and it is the repeated patterns of language that reveal actors' preferences and so construct communities and the individuals who work in them (Hyland, 2012). Corpora can show us how individuals collectively and repeatedly assemble markers of "who they are" through interaction.

So, these professional narrative genres are likely to represent the individual in a way which is valued by the community and as a result they express something of the tension between membership of that community and independence from it. This is what I have called proximity to a discipline, showing belonging, and taking a distinct position towards it, showing individuality. I am therefore using academic narratives to look at the two most contentious concepts in the social sciences, community and identity and in this paper I will argue two things:

- that these narratives tell us both about community and identity: that is, about disciplines and the people that make their professional lives in them;

- that corpus analysis is a productive way of studying both.

\section{Community and identity}

Community is something of a troubled concept, but we can see it as a shorthand for the practices and discourses routinely used by a particular group. The concept of community is particularly contentious when talking about disciplines as some writers see disciplines as little more than a convenient shorthand for practices that are less distinguishable and stable than we usually suppose (e.g. Mauranen, 2006). Others, writing from Post-modern positions, argue that the fragmentation of academic life has resulted in the death of disciplines (e.g. Gergen \& Thatchenkery, 1996). Like most communities, disciplines change constantly if slowly, so that new disciplines like bio-technology and gerontology spring up at the intersections of existing ones and achieve international recognition, while others like philology and astrology decline and disappear. 
10 Discipline is, however, a notion with remarkable persistence and the distinctive existence of disciplines can be informed by study of their rhetorical practices. Essentially they provide the context within which we learn to communicate and to interpret each other's talk, gradually acquiring the specialized discourse competencies to participate as members. They are the places we craft our identities, cement relationships and achieve recognition, where we find the tools and resources to live out our professional lives. We can therefore see disciplines as language using communities which help us join writers, texts and readers together (e.g. Geertz, 1973).

11 Because corpora allow us to focus on community practices, they also tell us something of how writers understand their communities: what their readers are likely to find persuasive and impressive. So these repeated rhetorical decisions don't just construct communities; they also construct individuals. Benwell and Stokoe (2006) argue that identity is "the ways that people display who they are to each other " so it doesn't exist within individuals but between them. It is the product of the interaction of individuals and is created within social relations. This is identity as the "performance" of a speaker or writer-what they do through the texts they engage in and the linguistic choices they make. In this view identity is something we create through the ways we participate in our everyday discourses. So while it may be a "performance", and subject to change, it is a performance which is re-inscribed in us over time. Identity comprises dispositions to behave in certain ways, to make particular discourse choices in routine situations.

12 As I have argued elsewhere (Hyland, 2012), these individual and collective identifications are symbolized in genres, so that speaking and writing in community-specific ways proclaims both individuality and membership of a group and a culture. Identity thus involves proximity: it depends on identification with something as we draw on the disciplinary schema which both shape and enable particular "speaking positions" and disable others (Baynham, 2006). At the same time, these broad templates for how we see and talk about the world are also the resources we need to present our own perspectives. Academic reputations are based on saying something new, but doing so in ways that are familiar to those we are trying to convince. So while proximity concerns how genre choices construct individuals as members, positioning is how these choices construct members as individuals.

Obviously everyone is different. Social class, ethnicity, gender, age and so on influence how we make sense of our disciplines and how we interact with colleagues in performing a professional identity. When acting as academics, however, we are acting in a restricted context which gives meanings to our language choices. We can see something of this in the three genres I have mentioned where self-representation is most explicit, the narrative genres of acknowledgements, article bios and academic homepages

\section{Identity in thesis acknowledgments}

14 I begin with a genre which initially seems to have little to do with identity. Acknowledgements, however, offer students an opportunity to give credit to institutions and individuals who have contributed to their thesis in some way and to make a favourable impression on readers. So while acknowledgements can act as a means of recognizing debts and achieving a sense of closure at the end of a long and demanding 
research process, they also reveal the writer as someone with a life beyond the page, an individual among academics.

Acknowledgements can tell a story to help create a professional and personal identity. Ben-Ari (1987), for example, comments on the role of acknowledgements in constructing a professional identity through their strategic role in "careering". In postgraduate acknowledgements this is achieved through the student's management of his or her relations to the disciplinary community and affiliation to particular research groups, leading figures or academic orientations. In a corpus of 240 acknowledgements accompanying Masters' dissertations and $\mathrm{PhD}$ theses written by Hong Kong students in six disciplines (Hyland, 2003; 2004), I discovered that students use this channel to not only recognize assistance and support, but also to construct a particular persona. Thus $95 \%$ of thanks included the reason for acknowledging the person which suggests that writers weren't only addressing the people they acknowledged but a much wider audience. In fact they were using the acknowledgement to construct a narrative for themselves as good researchers and sympathetic human beings.

The opening reflecting move, for example, allows students to publicly contemplate what they have gained through the research experience. Here writers can present a self free of academic conventions and reveal a real individual coping with and triumphing over, the exacting demands of research:

1) When I naively stepped onto this path of self-discovery, I hardly understood the academic, emotional and physical difficulties in doing a qualitative research and writing an academic paper. (SA PhD)

2) I feel I have learnt a lot from writing this thesis searching for the truth of science and life. This is the great treasure I will cherish not only in my future academic career but in my whole life. (Bio PhD)

Often there is an implication in these reflections that this tremendous effort and sacrifice deserves success. There is rhetorical intent, suggesting that the writer is a hard-working, conscientious individual, worthy of the degree:

3) This dissertation took almost three years from conception to completion. It involved countless cycles of exploration, inquiry, meditation, enlightenment, doubt, confusion, uncertainty, and perseverance. (AL PhD)

Thanking for academic help also displays the crafting of a professional self. PhD graduates are often anticipating a scholarly career, and a relationship with one's supervisor can secure the guidance and professional contacts of an established academic. So graduation is not the end of a relationship but the beginning of a more fruitful one. $S$ upervisors, in fact, appeared in every acknowledgement revealing the intellectual, and often emotional, obligation writers feel towards them.

4) The author would like to express his thanks to his supervisor Dr Wing Suen of School of Economics and Finance, the University of Hong Kong for his continuous guidance and giving the author a long lasting supervision, support and advice to do this research. (Bus PhD)

5) I would like to thank Dr Mun Fai Leung, my supervisor, for his patient and insightful guidance. (Engineering MSc)

More directly relevant to the public construction of an academic self, however, is the fact that who we identify with contributes to who we are, or are seen to be.

In the hard sciences the creation of knowledge is heavily dependent on the collaborative exchange of materials, information, and unpublished results which enmeshes the researcher into networks of reciprocal obligations. The effective construction of a 
credible academic persona therefore depends on who you know. Mentioning key figures can both gain the writer important credit and help project a scholarly persona.

Less obviously, we can also see the construction of identity in the acknowledgement of individuals and institutions who have provided resources such as data, technical help and financial support in completing the research process. While research often crucially depends on this kind of support, we can also see the textual production of an academic self in the detailing of thanks for prizes, prestigious scholarships, company sponsorships or travel grants. The following examples give some flavour of this:

6) The research for this thesis was financially supported by a postgraduate studentship from the University of Hong Kong, The Hong Kong and China Gas Company Postgraduate Scholarship, Epson Foundation Scholarship, two University of Hong Kong CRCG grants and an RCG grant. (Computer Science PhD)

7) This project was generously supported by funding from Hong Kong Polytechnic University's Staff Development Committee. Support has been forthcoming, too, from Cathay Pacific Airways in the form of complimentary air travel, which has allowed me to attend a number of overseas conferences and thereby bring the research to the attention of a wider audience. (Applied Linguistics PhD)

While the writer may feel obliged to refer to his or her funding agency, an examiner is unlikely to remain unimpressed by the writer's obvious talent and academic credentials.

Similar rhetorical intentions perhaps lie behind acknowledging individuals for organising conferences, reviewing articles, and collaborating on publishing projects. Particularly prevalent in the sciences, such gratitude clearly serves to enhance the writer's professional credentials:

8) A special acknowledgment is extended to Y.K. Leung at Stanford University for providing spreading resistance analysis and to Prof. Simon Wong for reviewing my IEDM paper. (Electronic Engineering PhD)

It is not difficult to see the textual construction of an academic self in these apparently innocent appreciations from a grateful graduate. They help mark the writer out as an individual whose academic talents have already been recognized and who may therefore be a deserving candidate for further honours.

In the human sciences, on the other hand, students more often thanked their subjects. This is a vivid example:

9) I would like to acknowledge the invaluable contributions of the hundreds of Filipino domestic workers in Hong Kong who unselfishly shared their lives and whose life's narratives essentially formed the basis of this dissertation. ... For reasons that they would understand, they would remain anonymous in this work. However, if someday they get the chance to read this work, I have no doubt that they will readily recognise their voices that have enlivened the many Sunday afternoons shared together in the parks, under the bridges and under the trees; in the sun and rain; enduring the heat and cold of the changing seasons. (AL PhD)

While subjects themselves are unlikely to read the text, quite subtle rhetorical intimations of professional commitment and academic competence can be communicated to professional readers, hinting at the authority and involvement of the writer and of trials overcome.

In addition to crafting a disciplinary persona in their acknowledgements, the fact that almost $40 \%$ of the thanks in the corpus were to friends and family suggests that the genre also provided them with the chance to project a more human face and a social identity. The fact that over $90 \%$ of these thanks identified family and friends by their full name 
indicates a clear awareness of audience and perhaps an opportunity for the writer to represent him or herself as a social person, something which is not available in the dissertation proper:

10) Gratitude expressed to all my research teammates including Miss Irene Kung, Miss Charlotte Yim and Mr Z. Q. Fang. Their humour and spiritual support smoothened my research progress. (Biology $\mathrm{PhD}$ )

11) My heartfelt gratitude especially to my two mentors, my mother, Mrs Gita Vyas and my father, Late, Dr V. K. Vyas who said that I could do whatever I set my mind to. (Applied Linguistics $\mathrm{PhD}$ ) personal bio statements which accompany research articles. Bios are authentically produced, naturally occurring texts constructed for a genuine purpose; a site where academics stake a claim to a certain version of themselves for their peers and institutions. This is probably the most explicit public assertion of self-representation in scholarly life. It is a genre where, in 50 to 100 words, academics present a narrative of expertise for themselves. It is particularly interesting as it sits in stark contrast to the article itself, which has been stripped of identifying information for blind peer review.

This is an opportunity for novice and experienced scholars alike to manage a public image through the careful recounting of achievement. It is an opportunity to make a claim for a particular identity through a genuine story-telling genre and so, unlike the familiar narrative interview, it does not produce self-conscious talk in a formal and lowstakes context. The following comments relate to a corpus of 600 bios taken from articles in three disciplines, Applied Linguistics, Electrical Engineering, and Philosophy, and also 
controlled for gender, with 100 bios by males and females in each discipline (Hyland \& Tse, 2012).

Using this corpus we looked at what people said about themselves (moves) and how they said it (based on verb types). Table 1 gives the frequencies per 1000 words of these features.

Table 1. - Overall Frequencies of Moves and Verb Types

\begin{tabular}{|l|l|l|l|l|l|}
\hline Moves & Totals & \% Words & Verb Types & Totals & \% Words \\
\hline Employment & 577 & 12.1 & Relational & 1,330 & 27.9 \\
\hline Research & 475 & 10.0 & Circum. & 138 & 2.9 \\
\hline Education & 296 & 6.2 & Intensive & 856 & 18.0 \\
\hline Publications & 283 & 5.9 & Possessive & 365 & 7.7 \\
\hline Achievement & 88 & 1.8 & Material & 1,103 & 23.2 \\
\hline Comm. services & 84 & 1.8 & Mental & 58 & 1.2 \\
\hline Personal profile & 50 & 1.1 & Verbal & 54 & 1.1 \\
\hline & & & Behavioural & 2 & 0.0 \\
\hline Total & $\mathbf{1 , 8 5 3}$ & $\mathbf{3 8 . 9}$ & & $\mathbf{2 , 5 4 8}$ & $\mathbf{5 3 . 5}$ \\
\hline
\end{tabular}

The table shows that writers overwhelmingly mentioned employment in their bios, always stating their current post and, together with research interests, this comprised over half of all move types in the corpus. In terms of representing these experiences, how they conveyed these moves, writers used relational and material process types (verb types) to discuss themselves in $95 \%$ of all clauses. The dominance of these process types stresses the importance of what the individuals claimed to be and what they do.

Relational process types predominantly clustered in what Halliday (1994: 119) calls intensive types, where a writer claims to be something, such as an assistant professor, a doctoral student or specialist in some field or other. These made up two thirds of all relational processes, with possessives, where writers stated they had some form of experience or research interest, comprising another $27 \%$. Circumstantial processes, where the process includes attribute of some kind, such as what the writer is interested in or an institution he or she is affiliated with, were also present in these texts but were far less common.

Looking at the move results in more detail, we find that gender is a relatively insignificant factor in influencing how writers represented themselves in bios with both men and women saying similar things about themselves in similar ways, the main difference being that men tended to foreground what they had formally accomplished by way of publications and service to the academic community rather more. Many women did not 
mention publications at all and simply offered a list of their educational experiences and professional qualifications.

Regarding rank, the data show an upward curve in the mention of research, employment, publication and achievement moves in traversing across the status cline. Senior scholars, in particular, were significantly more likely to discuss both their research interests and publication outputs. At the other end of the scale, research students largely used the opportunity to set out an educational background. In the absence of a clear publication record, they sought to manufacture a credible disciplinary identity by highlighting the fact they had taken a higher degree at a prestigious university. These credentials are also often supplemented by a specification of the writer's research interests, as here:

14) Hua Luan is currently a PhD student in School of Information, Renmin University of China. Her research interests include data warehousing, data mining, [...] (EE)

15) Charlotte Cobb-Moore is a doctoral candidate at Queensland University of Technology. Areas of research centre around young children's social interactions, with particular focus on their enactment of governance and [...] (AL)

While rank and gender seem relatively unimportant in identity construction, discipline was the most significant influence on what authors included in their bios. Perhaps the most striking difference is the importance engineers give to education, a category which they use to claim expertise in a specific area of study, thus promoting a scholarly insidercompetence in esoteric skills and knowledge:

16) She received the $\mathrm{PhD}$ degree (on thin-oxide technology and novel quasinonvolatile memory) from the University of California, Berkeley in 1999.

17) Irene Ntoutsi received her $\mathrm{PhD}$ in Informatics from the Department of Informatics, University of Piraeus, Greece.

This perhaps reflects a hard science apprenticeship-model where the education of $\mathrm{PhD}$ students is also an opportunity to research and publish as part of a team, making education more central to their bios. Research is typically less individually conceived and independently conducted here than in the soft knowledge fields and so for many engineers educational training is a significant aspect of their career profile and therefore tends to be given more attention in their bios than with writers in applied linguistics and philosophy.

In contrast, applied linguists crafted identities around their research interests, making a claim for credibility through insider expertise. These made up about a third of all acts in their bios:

18) Her research interests include human motivation and affect in a variety of applied contexts. (AL)

19) Jennifer de Winter's scholarship unpacks traditional and new media convergence within global markets. (AL)

41 This not only stakes a claim for academic credibility through familiarity with areas of current interest, but also aligns the writer with a particular camp of like-minded individuals.

Philosophers, on the other hand, prefer to highlight their publications. In philosophy $r$ esearch is spread out over a broad range of topics with long range solutions, slow publication times and books as preferred modes of dissemination (Becher \& Trowler, 2001). Because of this perhaps, publications take on a particular significance which is very different from the hard sciences where publication is frenetic and multiply authored. 

in terms of what we talk about but how we talk about it. Table 1 shows that relational forms increased with rank and material forms decreased with rank. So there is a shift from seeing our activities as something we do to something we are. Relational clauses present identity claims as they construe "being" and relational processes are mainly intensive, where a writer claims to be something, such as an assistant professor, doctoral student, etc. These claims are strengthened by use of identifying over attributive choices, particularly among professors, where they are over twice as frequent:

20) Bonnie Urciuoli is Professor of Anthropology at Hamilton College. (AL)

21) She is the author or co-author of over 40 technical papers and is the holder of two patents. (EE)

These choices give a definiteness and uniqueness to what is being claimed. They identify the writer by signalling that this is an important part of who they see themselves as. The bios of students and support staff, in contrast, use attributive options to signal class membership rather than a unique identity:

22) Sampath is a member of the Institute of Industrial Engineers.

23) $\mathrm{He}$ is a PhD student in Teaching English as a Second Language at UBC.

Status, therefore, has some impact on identity representation, but once again, it isn't status or gender but discipline which is the major influence on choice. Applied linguists, for example, were more likely to represent their work as an act of discovery and cognition through mental processes:

24) Her recent work examines the intersections of civic rhetoric and digital spaces.

(AL)

25) He investigates writing skill in classroom and workplace settings [...] (AL)

This adds a reflective and studious shade to a bio, representing the writer as a thinking academic rather than as an intellectual worker grinding out a quota of papers and presentations. Engineers, in contrast, and particularly male engineers, used more verbal forms to present themselves as arguers and discussers:

26) She is now lecturing at Sanjesh College of Computing and Statistics, Tehran, Iran. (EE)

27) He proposes the use of selectively grown epitaxial layers [...] (EE)

Like mental processes, verbal choices highlight human agency, bringing the role of the writer, lecturer or presenter to the forefront and so helping to construe the author explicitly in his or her scholarly role.

The greatest disciplinary variations, however, were in the ways writers employed relational processes and, in particular, philosophers' use of identifying relational clauses. Explicitly naming oneself as something or other is a significant aspect of identification and philosophers did this twice as frequently as applied linguists and nearly four times more than engineers. This option stresses a unique position for the writer and emphasizes an individual contribution:

28) Jeanne Openshaw is Senior Lecturer in Religious Studies at the University of Edinburgh. (Phil)

29) He has been President of the International Association for Aesthetics, Secretary

Treasurer of the American Society for Aesthetics, and [...] (Phil)

The prevalence of this pattern in philosophy may be due to the particularly individualistic ethos of the discipline which encourages writers to put their personal stamp on what they write. Research practices which stress interpretations and arguments

ILCEA, 31 | 2018 
as the creative insights of the author offers a way of positioning oneself in relation to colleagues which is very different to the self-effacing ideology which sees results as the collective endeavours of a team simply reporting experimental outcomes.

To sum up, while the bio seems a standardized genre with a limited range of options, these apparently bland descriptions are cross-cut by rank, gender and, most significantly, by discipline. This story-telling genre thus presents a narrative of the self, but one constructed out of the rhetorical options our communities make available. We gain credibility as disciplinary members and approval for our performances by positioning ourselves in relation to others using these discourses. In turn, we are ourselves positioned by these same discourses. So there is a tension here as, while we use genre conventions to index membership, claiming similarity, we gain reputations by taking a different stand or using a distinctive set of genre options. Positionings are not all the same and we might expect to find clearer examples of this in a genre which gives more textual space to selfrepresentation, the academic homepage.

\section{Identity in Academic Homepages}

Identity partly involves identification: identifying ourselves as belonging to a particular group by taking on its discourses, genres and understandings, what I have called proximity. Creating an academic homepage thus involves presenting the self by selecting materials likely to be valued by a particular group; it means making an identity claim. But there are tensions here as identity has become a marketing tool for universities who frequently manage this genre in ways which promote the institution at the expense of the individual. As Thoms and Thelwell (2005) observe:

The institution merely constructs academics in the model that is ideologically suited in order to promote the institution. Academics are thus denied any autonomous subjectivity construction, and yield to the constructed display items in the university electronic window.

The individuality of academics is marginalized in the name of university branding, suppressing a multi-dimensional view of the person to better showcase the university.

To regain some control over their representations, many academics create their own pages and to understand differences in the claims being made for the individual subjects I compared differences in the two versions of this genre. This involved examining a corpus of 100 homepages in philosophy and physics: 50 university hosted and 50 individual pages by the same authors and taking equal numbers of full professors and Assistant Professors and of men and women from each discipline (Hyland, 2011). I studied the visual design, hyperlinks, and textual representations, all of which are potential materials to construct identity through proximity to community-valued practices and experiences while simultaneously using these materials to position oneself as an individual player.

Visual representation is important in constructing identity in homepages and the most striking feature of the university staff pages is their glossy uniformity. Design, format, colour and images are determined by the institution and duplicated for every member in a department. While located in different disciplines, universities, and countries, the pages in figures 1 and 2 have a similar grid structure and narrow colour range. The pages are dominated by banner headings carrying institutional logos and department and university names, and by sidebars with departmental information. These features act as symbols of ownership which remove agency and position the individual as an employee. 
Following left to right reading conventions, for example, the text on the left is scanned first. It is the "given" of the text, providing the context in which we "read" the author himself. The institutional context is therefore the point of departure for the representation of the academic's identity.

Figure 1. - A Harvard academic university homepage

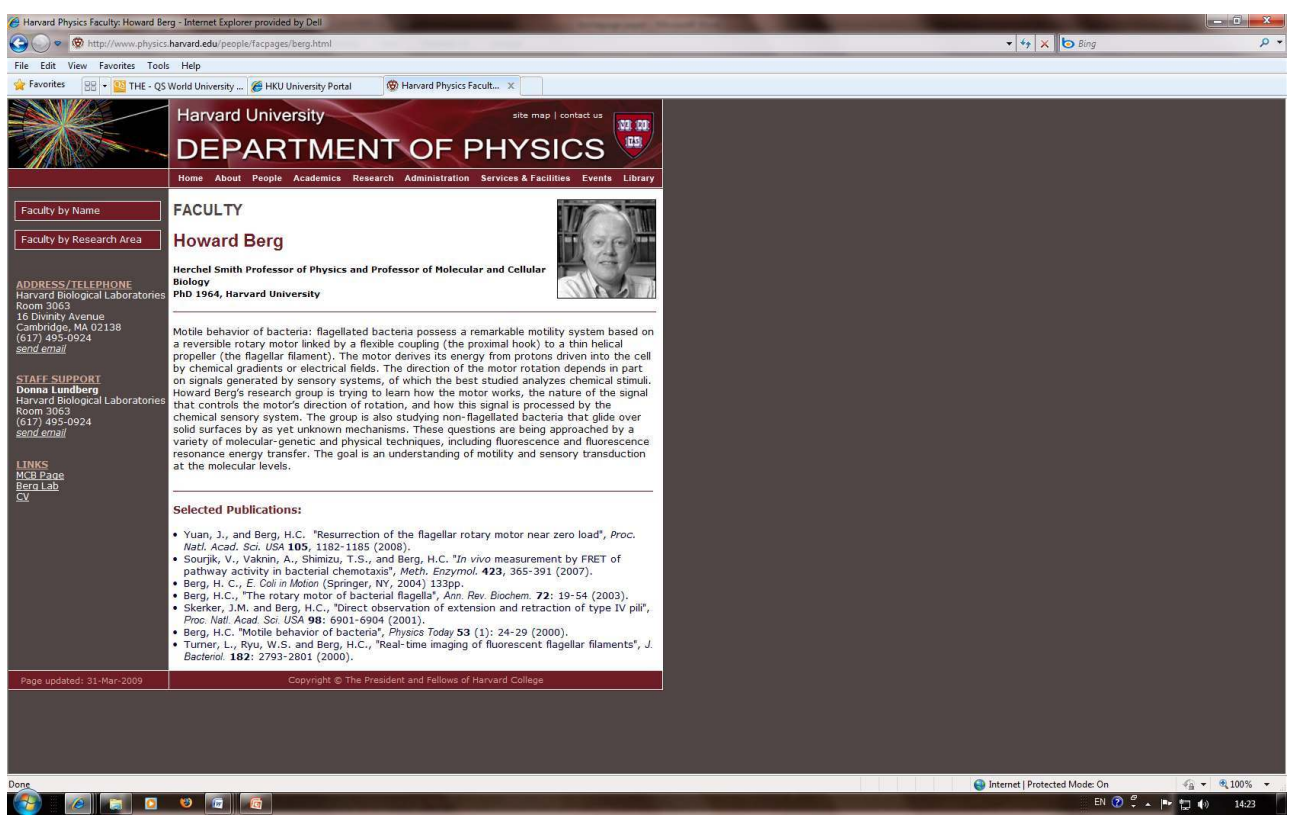

Figure 2. - University College London academic university homepage

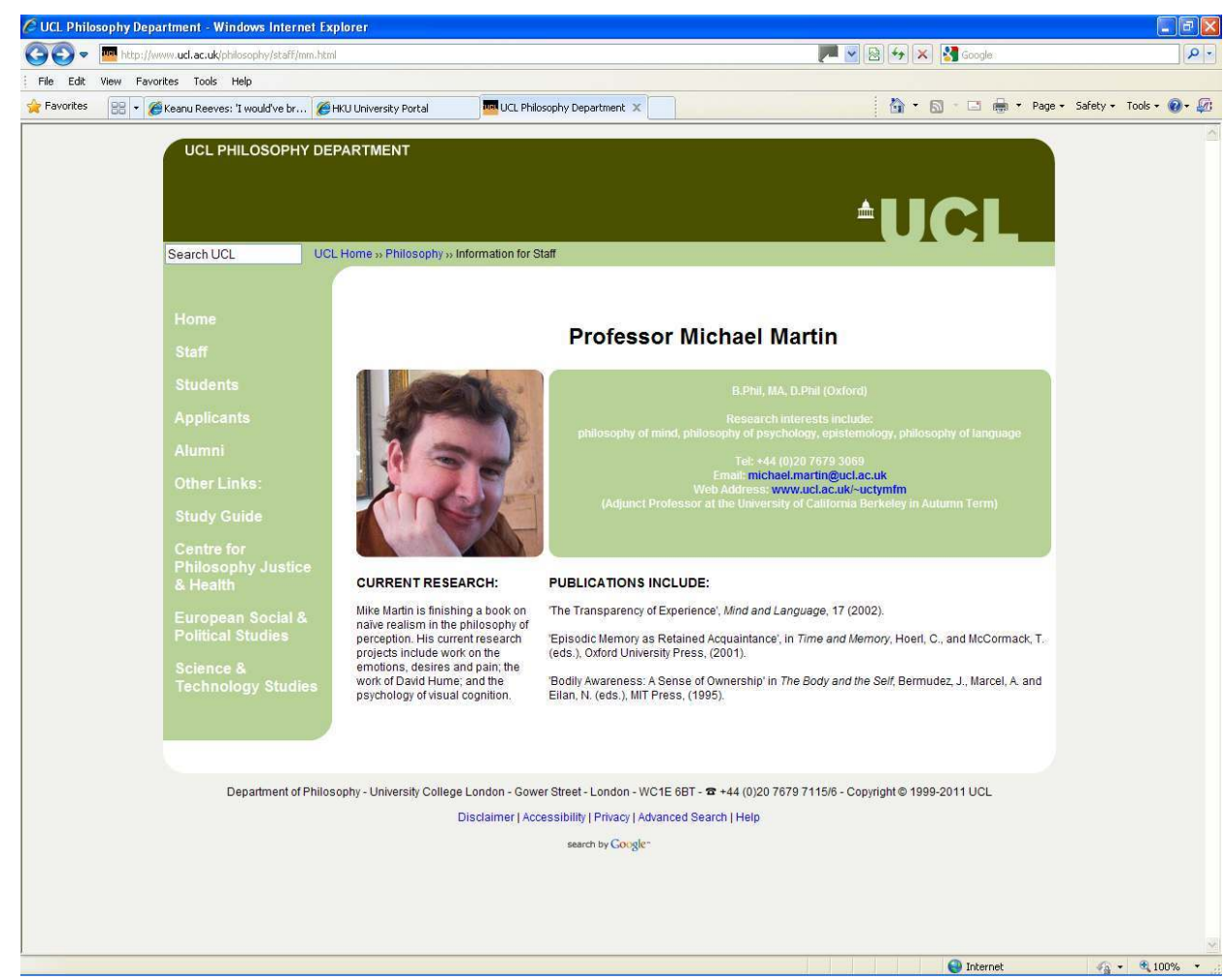


by creating a network of personally meaningful connections. When given a choice, authors reduced links to their university and department, which fell to $6.5 \%$ and $5.3 \%$, respectively, and increased them to their publications and disciplines. Links to publications shot up from $14.2 \%$ to $49 \%$ and most academics linked to their pdfs and reference lists. But disciplinary links are also far more important here, rising from $4.8 \%$ to $10 \%$, taking readers to labs, journal sites, professional associations, and so on. Thus authors used their personal pages to showcase themselves as academics rather than their institutions.

Despite these differences, however, there were considerable resemblances in the ways authors described themselves with over $80 \%$ of the pages mentioning jobs, research and publications and only $11 \%$ giving any personal information at all. of the 800 links on personally constructed homepages just 88 (10.8\%) referred readers to non-work pages, usually personal interest and hobby sites, another third, however, simply loaded a curriculum vitae which re-presented the writer's academic credentials. So while some used their personal page as a chance to present an academic-self more creatively, most remained adamantly professional scholars. But while academics aren't obliged to post personal information, there is a marked absence of any sense of author individuality. A homepage generates strong expectations of personal disclosure and the decision to present only a professional suggests that the bland academic presented is all there is. 


\section{Conclusions}

60 traditional problem-solution format, they are available to academics to tell stories about
themselves, to present themselves in a way that isn't possible in the confines of the more central, evaluated, knowledge-producing texts. Like those genres, however, acknowledgements, bios and homepages show how we choose our words to connect with others and present ourselves in ways which have value in our communities. These communities privilege certain values and ways of making meanings, so that our selfrepresentations relate us to our disciplines.

61

In one sense, then, identity means constructing credibility: we seek to present ourselves as recognisable, and recognisably competent, students, teachers, nurses, fishmongers, or whatever. We do this by negotiating a self which is coherent and meaningful to both the individual and the group. This means, of course, that identity is not simply a matter of personal choice. We cannot just be whoever we want to be. But it also means that we are not just prisoners of our social groups. The narratives we present, the stories we tell of ourselves are not created in a social vacuum. These genres are constraining as they restrict what rhetorical habits we can bring from our past experiences and what we use from those available.

But genres are the ways we relate independent beliefs to shared experience and so using corpora to study them shows us something of how, through our repeated choices from a repertoire of options, we display ourselves as the people we want to be. As such, the production of narratives of identity is always the production of community and of self.

\section{BIBLIOGRAPHY}

BARTHES Roland (1975), “An Introduction to the Structural Analysis of Narrative”, New Literary History, Baltimore: The Johns Hopkins University Press, 6(2), 237-272.

BAYNHAM Mike (2006), "Performing self, family and community in Moroccan narratives of migration and settlement", A. de Fina, D. Schiffrin \& M. Bamberg (eds), Discourse and Identity. Cambridge: Cambridge University Press, 376-397.

BECHER TONY \& TROWLER Paul (2001), Academic tribes and territories: intellectual enquiry and the culture of disciplines (2nd ed.), Milton Keynes: SRHE/OUP.

BEN-ARI Eyal (1987), “On acknowledgements in ethnographies”, Journal of Anthropological Research, 43(1), 63-84.

BENWELl Bethan \& STOKоE Elizabeth (2006), Discourse and Identity, Edinburgh: Edinburgh University Press.

BLOCK David (2006), Multilingual Identities in a Global City, Basingstoke: Palgrave.

GEERTZ Charles (1973), The Interpretation of Cultures, New York: Basic Books. 
GERGEN Kenneth J. \& THATCHENKERY Tojo J. (1996), “Organisational science as social construction: postmodern potentials", The Journal of Applied Behavioral Science, 32(4), 356-77.

GIDDENS Anthony (1991), Modernity and Self-identity: Self and Society in the Late Modern Age, Cambridge: Polity Press.

GILBERT Nigel G. \& MULKAY Michael (1984), Opening Pandora's Box: a Sociological Analysis of Scientists' Discourse, Cambridge: Cambridge University Press.

HYLAND Ken (2003), "Dissertation acknowledgments: the anatomy of a Cinderella genre", Written Communication, 20(3), 242-268

HYLAND Ken (2004), Disciplinary discourses: Social interactions in academic writing, Michigan: University of Michigan Press.

HYLAND Ken (2011), “The presentation of self in scholarly life: identity and marginalization in academic homepages", English for Specific Purposes, 30(4), 286-297.

HYLAND Ken (2012), Disciplinary identities, Cambridge: Cambridge University Press.

HYLAND Ken (2013), "Individuality or conformity? Identity in personal and university academic homepages", Computers and Composition, 29, 309-322.

HYLAND Ken \& TSE Polly (2012), “'She has received many honours': Identity Construction in Article Bio Statements", Journal of English for Academic Purposes, 11, 155-165.

IVANIC Roz (1998), Writing and Identity: The Discoursal Construction of Identity in Academic Writing, Amsterdam: John Benjamins.

KROSKRITY Paul V. (2000), Regimes of language: ideologies, polities, and identities, Santa Fe: SAR Press.

MAURANEN Anna (2006), "Speaking the Discipline: Discourse and Socialisation in ELF and L1

English”, K. HYLAND \& M. BONDI (eds), Academic Discourse Across Disciplines, Frankfort: Peter Lang.

THOMS Lesley \& THELWALl Mike (2005), “Academic home pages: reconstruction of the self”, First Monday, 10(12), < https://journals.uic.edu/ojs/index.php/fm/article/view/1302/1222>.

\section{ABSTRACTS}

Understanding narrative as the stories we tell about ourselves in our professional academic lives, I focus here on the genres which, most explicitly, allow us to do this. I want to explore how we construct representations of ourselves, what I shall call "identity narratives", in three rather neglected academic genres where the requirements of anonymity and impersonality are more relaxed. In thesis acknowledgements, bio statements and personal webpages writers are released from formal conventions of disciplinary argument and have an opportunity to reveal something of how they want to be seen by others. The question arises, however, of how they use the opportunities these story-telling genres offer.

Considérant le récit dans la perspective des histoires que nous racontons à propos de nousmêmes dans le cadre de nos vies professionnelles d'universitaires, je m'intéresse aux genres qui nous permettent de le faire de manière plus explicite. Mon objectif ici est d'explorer comment se construisent des représentations de soi, ce que j'appellerai des " récits identitaires ", dans trois genres académiques peu explorés jusqu'ici, où les exigences d'anonymat et de dépersonnalisation sont moins contraignantes. Les auteurs des pages de remerciements en début des thèses, des pavés bio et des pages web personnelles sont dégagés des contraintes formelles qui régissent 
l'argumentaire disciplinaire et disposent d'une ouverture qui leur permet de révéler une partie de la façon dont ils souhaiteraient être perçus par autrui. La question se pose, cependant, de savoir comment ces auteurs exploitent les opportunités que ces genres narratifs offrent.

INDEX

Keywords: narrative, identity, acknowledgements, personal webpages, academic bios Mots-clés: récits, identité, remerciements, pavés bio, sites web personnels

\section{AUTHOR}

\section{KEN HYLAND}

University of East Anglia (UK) 